\title{
Model Komunikasi Korporat Sari Ater Hotel \& Resort Dalam Menghadapi Revolusi Industri 4.0
}

\author{
Poppy Ruliana ${ }^{1}$, Puji Lestari ${ }^{2}$, Susi Andrini ${ }^{3}$ \\ ${ }^{1}$ Program Studi Magister Ilmu Komunikasi, ${ }^{3}$ Program Studi Ilmu Komunikasi \\ Sekolah Tinggi Ilmu Komunikasi (STIKOM) InterStudi \\ ${ }^{2}$ Program Studi Ilmu Komunikasi FISIP \\ Universitas Pembangunan Nasional "Veteran" Yogyakarta \\ Email: Poppyruliana30@gmail.com; pujilestariupn@gmail.com; ussie69@gmail.com
}

\begin{abstract}
The importance of implementing the corporate communication model at Sari Ater Hotel \& Resort in the face of the industrial revolution 4.0 is faced with the use of new media and the effects of these changes on the company. The purpose of this study was to find out and find the corporate communication model of Sari Ater Hotel $\mathcal{E}$ Resort. This study aims to find the corporate communication strategy of Sari Ater Hotel \& Resort in the face of the 4.0 industrial revolution. The study used qualitative descriptive methods with case studies, where data was obtained through in-depth interviews (in-depth interviews) and observations of informants (marketing manager, corporate communication and public relations). The results of this study indicate that the sosial media communication model for corporate Sari Ater models are relevant to research because in reality digital media has an influence on the implementation of PR Sari Ater Hotel $\mathcal{E}$ Resort activities and has even been used as a medium to interact with the public, both internal and external public because the internet can be known as various information and issues that develop or changes that occur so that a PR practitioner Sari Ater Hotel E Resort can access all information required according to the needs of the organization. The research findings are in the form of combining one-way and two-way communication models such as the findings of the concept of corporate communication models at Sari Ater Hotel \& Resort in the face of the linear and circular industrial revolution 4.0 .
\end{abstract}

Keywords: Corporate Communication, Communication Model, Industry Revolution, Sosial Media

\begin{abstract}
Abstrak
Pentingnya implementasi model komunikasi korporat di Sari Ater Hotel \& Resort dalam menghadapi revolusi industry 4.0 dihadapkan pada penggunaan media baru dan efek dari perubahan ini pada perusahaan. Tujuan penelitian ini adalah untuk mengetahui dan menemukan model komunikasin korporat Sari Ater Hotel \& Resort Penelitian ini bertujuan menemukan strategi komunikasi korporat Sari Ater Hotel \& Resort dalam menghadapi revolusi industri 4.0. Penelitian menggunakan metode kualitatif deskriptif dengan studi kasus, dimana data diperoleh melaluin wawancara mendalam (in-depth interview) dan observasi terhadap informan (Manajer pemasaran, Corporate Communication dan Public relations). Hasil penelitian ini menunjukkan bahwa model komunikasi media sosial untuk korporat Sari Ater model relevan dengan penelitian karena kenyataannya media digital memberi pengaruh terhadap pelaksanaan kegiatan PR Sari Ater Hotel \& Resort bahkan telah dijadikan sebagai media untuk berinteraksi dengan public, baik public internal maupun public eksternal karena melalui internet dapat diketahui berbagai informasi mau pun isu-isu yang berkembang atau perubahan yang terjadi sehingga seorang praktisi PRSari Ater Hotel \& Resort dapat mengakses seluruh informasi yang diperlukakan sesuai kebutuhan organisasi. Temuan penelitian berupa kombinasi model komunikasi satu arah dan dua arahberupa temuan konsep model komunikasi korporat di Sari Ater Hotel \& Resort dalam menghadapi revolusi industry 4.0 bersifat linier dan sirkuler
\end{abstract}

Kata kunci: Komunikasi Korporat, Model Komunikasi, Revolusi Industri, Media Sosial

\section{Pendahuluan}

Komunikasi korporat memainkan peran yang semakin besar dalam lingkungan bisnis perhotelan dan pariwisata yang makin 
kompetetif, karena harus melaksanakan "pengamanan brand image" yang merupakan tugas pokok sebuah perusahaan. Berkat pengamanan yang memadai brand image akan berkembang menjadi reputasi perusahaan (corporate reputation), maka tidak mengherankan bila reputasi perusahaan kemudian dipercaya sebagai senjata sakti untuk memenangkan persaingan dan menjamin kelangsungan hidup (survival) di tengah kegalauan global di era revolusi industry 4.0 saat ini (Anthony Bianco, dalam Ruliana, 2014). Industri 4.0 terdapat:

"Contemporary industrial revolution is the answer to information age problems which are the consequence of the unreliableness of human resources (especially when data are enhancement) or individualization of customer expectations" (Wyrwicka \& Mrugalska, 2017).

Ungkapan "selalu mampu menemukan diri sendiri" berarti dengan seksama organisasi mampu membina reputasi yang telah dicapai. Revolusi industri 4.0 merupakan istilah baru yang hadir dari ide revolusi industri keempat. Berbeda dengan revolusi industri sebelumnya, revolusi industri generasi ke-4 memiliki skala, ruang lingkup, dan kompleksitas yang lebih luas. Kemajuan teknologi baru yang mengintegrasikan dunia fisik, digital, dan biologis telah memengaruhi semua disiplin ilmu, ekonomi, industri, dan pemerintah. Banyak bidang mengalami terobosoan berkat kemajuan teknologi baru (Rosyadi, 2018). Konsep "Industrial 4.0" muncul pertama kali dalam sebuah artikel yang diterbitkan oleh pemerintah Jerman pada November 2011, sebagai strategi teknologi tinggi untuk tahun 2020. Setelah mekanisasi, elektrifikasi, dan informasi, tahap keempat industrialisasi dinamai " Industri 4.0". Pada April 2013, istilah "Industri 4.0" muncul lagi di sebuah pameran industri di Hannover Jerman, dan dengan cepat naik sebagai strategi nasional Jerman. Beberapa tahun terakhir, "Industri 4.0" telah banyak dibahas, dan telah menjadi hotspot bagi sebagian besar industri global dan industri informasi. Industry 4.0 akan menjadi revolusi industri baru, yang akan memiliki pengaruh besar pada industri internasional (Zhou, 2015). Industri 4.0 melalui tiga revolusi industri pertama, manusia telah menyaksikan dan menciptakan teknologi mekanik, listrik dan informasi, yang ditujukan untuk meningkatkan produktivitas proses industri. Revolusi industri pertama meningkatkan efisiensi melalui penggunaan tenaga air, peningkatan penggunaan tenaga uap dan pengembangan peralatan mesin; revolusi industri kedua membawa listrik dan produksi massal (jalur perakitan); revolusi industri ketiga semakin mempercepat otomatisasi menggunakan elektronik dan teknologi informasi, dan sekarang revolusi industri keempat yang mengintegrasikan dunia nyata (Cyber Physical System) dengan era informasi untuk pengembangan industri di masa depan, seperti pada gambar 1 .

Penelitian European Parliamentary yang dikutip Davies (Ruliana dan Lestari, 2019) menjelaskan revolusi industri pertama terjadi di Inggris pada tahun 1784 di mana penemuan mesin uap dan mekanisasi mulai menggantikan pekerjaan manusia. Revolusi yang kedua terjadi pada akhir abad ke19 di mana mesin-mesin produksi tenaga listrik digunakan untuk kegiatan produksi 


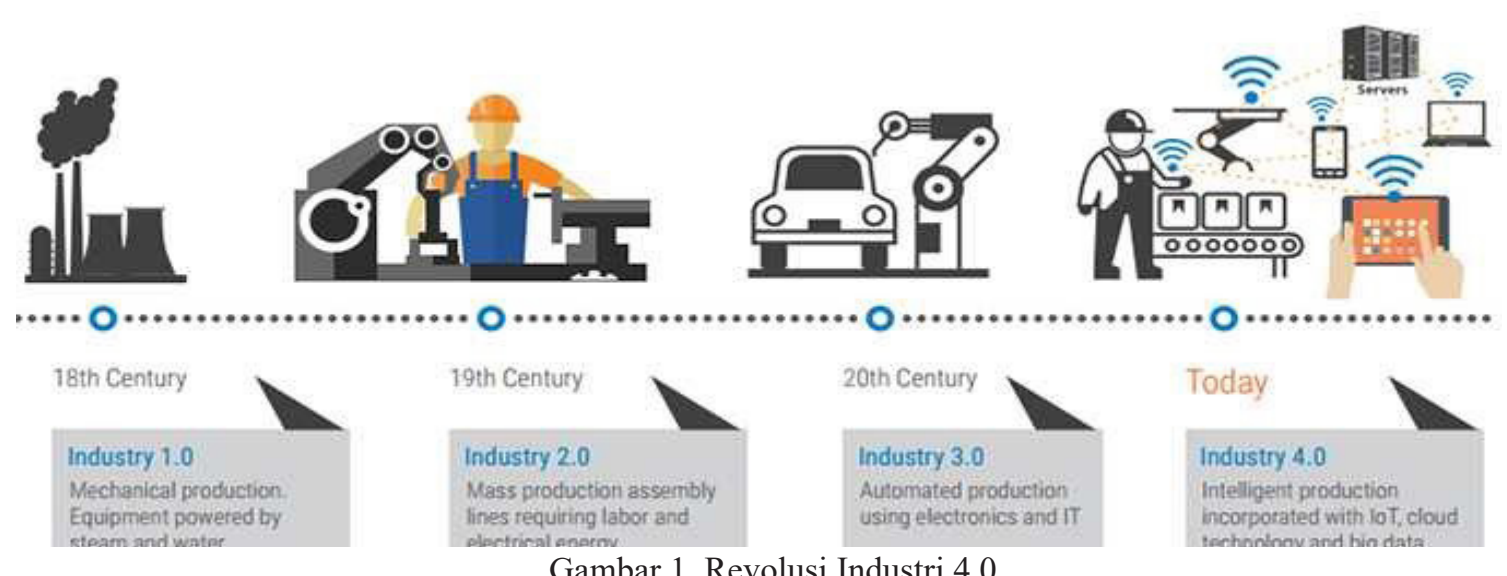

Gambar 1. Revolusi Industri 4.0

Sumber: Industry 4.0: Towards Future Industrial Opportunities and Challenge, 2019

secara masal. Penggunaan teknologi komputer untuk otomasi manufaktur mulai tahun 1970 menjadi tanda revolusi industri ketiga. Saat ini, perkembangan yang pesat dari teknologi sensor, interkoneksi, dan analisis data memunculkan gagasan untuk mengintegrasikan seluruh teknologi tersebut ke dalam berbagai bidang industri termasuk industri perhotelan dan pariwisata.

Platform industri 4.0 (diterjemahkan dari bahasa Jerman dan Inggris) istilah industri 4.0 adalah singkatan dari revolusi industri keempat. Dapat dipahami sebagai tingkatan baru dari organisasi dan kontrol atas seluruh rantai nilai dari siklus hidup sebuah produk (hajat hidup). Hal tersebut dibuktikan pada sikap masyarakat atau pelanggan (kaitannya dengan industri) yang semakin individual. Siklus ini dimulai pada ide produk, mencakup penempatan dan manufaktur pesanan, sampai pada akhirnya pengiriman produk untuk pelanggan, dan diakhiri dengan daur ulang, yang mencakup semua layanan yang dihasilkan. dasar untuk revolusi industri keempat adalah ketersediaan untuk semua informasi yang relevan secara real-time dengan menghubungkan semua contoh yang terlibat dalam suatu siklus. Kemampuan untuk menjadi bagian dari siklus aliran merupakan nilai tambah yang optimal. Koneksi orang-orang, bendabenda dan sistem menciptakan hubungan dinamis, otonom, real-time, siklus inilah yang kemudian dimaksimalkan baik di dalam dan di seluruh lingkup kehidupan, seperti perkembangan media sosial. Berbeda dengan suasana dulu, individu tidak memerlukan platform tersebut untuk menjalin sebuah hubungan sosialnya. (Ruliana dan Lestari, 2019)

Pengguna internet di Indonesia mengalami perkembangan yang pesat sejak tahun 2013 hingga 2019 seperti pada tabel 1.

Pada tabel 1.0 menggambarkan mengenai jumlah pengguna media sosial di Indonesia yang semakin meningkat dari tahun ke tahun. Hal ini diperkuat oleh pernyataan kominfo (web kominfo 19 November 2018), bahwa Kementerian Kominfo Republik Indonesia menyebutkan bahwa penguna internet Indonesia mencapai 54 persen atau 143 juta dari 265 juta jiwa 
Tabel 1 Pengguna Sosial Media di Indonesia

\section{Social Network Users and Penetration in Indonesia,} 2013-2019

\begin{tabular}{|c|c|c|c|c|c|c|c|}
\hline & 2013 & 2014 & 2015 & 2016 & 2017 & 2018 & 2019 \\
\hline $\begin{array}{l}\text { ocial network } \\
\text { sers (millions) }\end{array}$ & & & & & & & 10 \\
\hline —\% change & $29.9 \%$ & $15.4 \%$ & $12.1 \%$ & $13.5 \%$ & $12.3 \%$ & $9.4 \%$ & 8.9 \\
\hline -\% of internet users & $76.7 \%$ & $77.0 \%$ & $77.4 \%$ & $79.8 \%$ & $81.9 \%$ & $82.0 \%$ & $82.2 \%$ \\
\hline -\% of population & $22.3 \%$ & $25.4 \%$ & $28.2 \%$ & $31.8 \%$ & $35.4 \%$ & $38.4 \%$ & $41.4 \%$ \\
\hline \multicolumn{8}{|c|}{$\begin{array}{l}\text { Note: internet users who use a social network via any device at least once } \\
\text { per month } \\
\text { Source: eMarketer, Dec 2014; confirmed and republished, July } 2015\end{array}$} \\
\hline
\end{tabular}

Sumber: eMarketer Chart, 2016

penduduk Indonesia. Dari 54 persen tersebut merupakan bagian dari pengguna jasa pariwisata. Sari Ater Hotel dan Resort yang menjadi objek penelitian ini juga harus memperhatikan aspek teknologi komunikasi sebagai model komunikasi korporat. Hal ini dimaksudkan untuk menyesuaikan dalam pemberian pelayanan jasa pariwisata yang dibutuhkan oleh calon konsumen dan konsumen. Sebagian besar konsumen menggunakan media sosial untuk mengakses jasa pariwisata. Media sosial didefinisikan oleh Komito dan Bates (2009) sebagai aplikasi Internet, yang memastikan interaksi yang meningkat di antara pengguna Internet melalui konten yang dibuat pengguna. Konten tersebut dapat berbeda dan termasuk foto, video, dan komentar tekstual informasi dan komunikasi terutama dalam sosial media.. Palmer dan Koening-Lewis (2009) mengkarakterisasi media sosial sebagai aplikasi online, platform dan media yang ditargetkan untuk membuat interaksi, kerja sama dan pertukaran konten lebih mudah. Pentingnya media sosial dikaitkan dengan kemungkinan interaksi antara pengguna dan komunitas, dan interaksi tersebut dicirikan oleh nonsinkronisme, keterusterangan, dan biaya rendah. Patti Anklam (2009) mendefinisikan media sosial sebagai seperangkat alat perangkat lunak dan aplikasi Internet, yang memastikan pengembangan hubungan manusia dan dipersonalisasi dengan mengidentifikasi individu berdasarkan nama (Kazaka, 2011). Dengan demikian, praktisi Public Relations (PR) dituntut untuk menguasai teknologi Hal ini dibenarkan oleh Juwita, Rina (2017:56), mengatakan bahwa:

"Perkembangan media sosial membawa dampak yang luar biasa terhadap profesi PR. Hal tersebut menawarkan kesempatan baru dan keahlian baru bagi keberhasilan praktik-praktik PR. Tekanan kebutuhan akan keahlian media sosial dalam profesi PR mendorong pada penciptaan karir baru, di mana para praktisi harus menyadari bagaimana pemasaran media sosial dapat digunakan bagi komunikasi korporat. Pemasaran media sosial merupakan media yang sangat efektif bagi profesi PR karena media tersebut menawarkan saluran baru bagi keberhasilan komunikasi yang diperlukan antara organisasi dengan publik-publiknya, serta kesempatan baru agar komunikasi tersebut menjadi lebih 
bermakna dan bermanfaat bagi kedua belah pihak."

Perkembangan teknologi melalui media digital menuntut praktisi PR mengembangkan model komunikasi korporat dengan pemanfaatan media sosial/ media digital melalui, model nilai tambah (value added model) yang mencerminkan proses komunikasi perusahaan di media sosial diusulkan oleh Kazaka, (2013). Model ini mencakup elemen-elemen berikut: mendengarkan, pesan, pilihan media sosial, tingkat personifikasi, interaksi, nilai tambah, tekanan komunitas, tekanan strategi (Gambar. 1). Nilai tambah adalah elemen kunci dari model ini karena menggabungkan semua bagian lain dari model. Model visualisasi dan klarifikasi konseptualnya dijelaskan di baawah ini di bawah ini;

\section{1) Mendengarkan}

Mendengarkan memberikan analisis konten media sosial untuk menentukan pandangan pengguna tentang perusahaan atau merek, produk atau layanan, peristiwa atau situasi tertentu. Pada tahap ini, Fungsi Cermin menurut Van Riel (Kazaka, 2013) membantu untuk memprediksi dampak pada audiens. Studi ini menunjukkan bahwa $80 \%$ pengguna menghargai situasi tersebut, ketika perusahaan memberikan jawaban atas pertanyaan mereka di media sosial. Selain itu, 71\% menghargai bahwa perusahaan merespons kritik di media sosial. Praktik-praktik ini dapat diimplementasikan jika perusahaan memonitor konten media sosial. Selain itu, pengguna juga dapat membantu perusahaan menghasilkan atau menguji

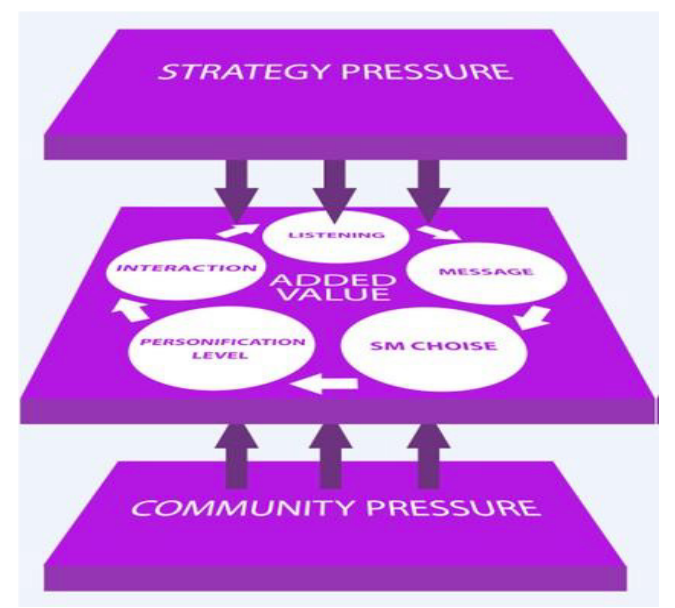

Gambar 2. The Model of Corporate Communication in Sosial Media

Sumber : Olga Kazaka, 2013

ide. Disarankan untuk memulai dengan elemen ini untuk menganalisis situasi di media sosial, serta sebelum keterlibatan aktif dalam komunikasi. Struktur lingkaran Model menunjukkan bahwa perlu untuk kembali ke elemen mendengarkan selama proses komunikasi, serta mencerminkan karakter komunikasi yang berkelanjutan. Analisis situasi tidak terbatas pada analisis komunikasi pelanggan perusahaan, tetapi juga mencakup analisis komunikasi non-klien, kelompok kepentingan lain, karyawan, dan pesaing. ( Kazaka, 2013).

\section{2) Pesan}

Berdasarkan hasil dari tujuan mendengarkan dan komunikasi, perusahaan merumuskan pesan-pesannya. Penting untuk membuat pesan perusahaan berfungsi sebagai faktor yang mempengaruhi pilihan media sosial. Penelitian menunjukkan bahwa kepentingan perusahaan dan pengguna bertepatan, ketika pesan menginformasikan produk atau layanan perusahaan (75\% perusahaan, yang berkomunikasi di media sosial, 
merumuskannya sebagai tujuan mereka di lingkungan ini; 84\% daripengguna memiliki sikap positif terhadap praktik tersebut di media sosial), perkembangan terbaru di bidangnya masing-masing ( $82 \%$ perusahaan menganggapnya sebagai tujuan dasar di media sosial, dan 79\% pengguna memiliki sikap positif terhadapnya), memberikan jawaban kepada pertanyaan pengguna $(52 \%$ perusahaan percaya bahwa lingkungan media sosial menguntungkan untuk tugas ini, dan $80 \%$ pengguna memiliki sikap positif terhadap praktik semacam itu).

\section{3) Pilihan media sosial}

Selanjutnya, media sosial tertentu, di mana pesan akan dilaporkan, dipilih. Pilihannya tergantung pada kemampuan teknis media sosial, serta preferensi pengguna sehubungan dengan penggunaan media. Studi ini menunjukkan bahwa perusahaan cenderung memilih media sosial yang berbeda untuk mengkomunikasikan pesan yang berbeda. Misalnya, Twitter digunakan untuk memberi tahu pengguna tentang perkembangan terakhir di bidangnya masing-masing, forum digunakan untuk mencari tahu pendapat pengguna para pesaing, sedangkan komunikasi dengan karyawan dikelola melalui blog perusahaan.

\section{4) Tingkat personifikasi}

Setiap perusahaan juga membuat keputusan, apakah pesannya akan dikirim di media sosial yang mengidentifikasi hubungan pengguna dengan perusahaan atau secara anonim. Internet dan media sosial tertentu memberikan peluang untuk mempublikasikan informasi baik secara pribadi - dalam profil perusahaan resmi di jejaring sosial dan di blog, dan secara anonim - di forum, wiki, dan sumber daya lainnya. Lingkungan yang dipersonalisasi dan anonim ada secara paralel. Studi ini mengungkapkan bahwa 90\% pengguna menganggap positif praktik tersebut, ketika sebuah perusahaan berkomunikasi di media sosial melalui profil yang dipersonifikasikan. Di sisi lain, dalam posisi ini perwakilan perusahaan memutuskan, apakah pesannya ditujukan kepada pengguna tertentu atau grup pengguna yang tidak diketahui

\section{5) Interaksi}

Interaksi dengan publik dan keterlibatannya dalam komunikasi korporat melalui media sosial memungkinkan menjangkau audiens yang lebih luas, serta menguji atau menghasilkan ide-ide baru. Namun, interaksi harus didasarkan pada pemahaman tentang minat dan kebutuhan audiens karena pengguna kurang positif dengan penilaian situasi, ketika perusahaan mengikuti profil perusahaan dan terlibat dalam diskusi. Berikut adalah keengganan pengguna untuk mengizinkan perusahaan masuk "ke wilayah mereka", jadi penting bagi perusahaan dalam komunikasi dengan pengguna untuk membiarkan mereka menarik diri dari komunikasi dan memilih sendiri, kapan akan terlibat. Penting juga bagi perusahaan untuk membuat konten yang akan berharga bagi pengguna. Pada tahap ini, karakteristik tertentu dari model 
simetris dua arah Grunig (2008) muncul: menurutnya kedua pihak berubah sampai batas tertentu selama komunikasi.

\section{6) Nilai tambah}

Nilai tambah adalah elemen yang sangat penting dari proses komunikasi perusahaan di media sosial. Ini mempengaruhi semua elemen lainnya, dengan menerapkan setiap fase komunikasi, perwakilan perusahaan harus memikirkan nilai yang ditawarkan oleh aktivitas ini kepada pengguna media sosial dalam lingkup kepentingan perusahaan. istilah "nilai tambah" untuk menggambarkan nilai tersebut, diintegrasikan dengan pihak yang berkomunikasi dalam komunikasinya, yang membantu pengguna untuk memecahkan beberapa masalah, untuk meningkatkan kualitas hidup, untuk memfasilitasi kehidupan sehari-hari atau proses komunikasi.

Adanya nilai tambah menentukan apakah komunikasi perusahaan akan berhasil di media sosial. Perlunya nilai tambah ditunjukkan oleh temuan penelitian berikut: paling sering pengguna menunjukkan bahwa termotivasi untuk mengikuti profil perusahaan jika pengguna dapat menerima informasi berharga atau saran praktis, pengguna harus memilih perwakilan perusahaan untuk berkomunikasi dengan baik dan lebih suka ahli, yang dapat memberikan informasi spesifik dan berguna. Lebih lanjut, dua pertiga pengguna menyatakan bahwa pengguna memiliki sikap positif terhadap situasi tersebut, ketika sebuah perusahaan berkomunikasi tentang topik, yang menarik bagi pengguna, tetapi tidak sepenuhnya terkait bisnis. Demikian pula ketika nilai tambah ekonomi mencerminkan nilai finansial yang telah ditambahkan perusahaan pada produk atau layanannya, nilai tambah komunikatif memfasilitasi pencapaian tujuan perusahaan dengan bantuan alat komunikasi.

\section{7) Tekanan strategi dan tekanan masyarakat}

Setiap elemen dari model mengalami dampak dari dua tekanan. Di satu sisi, ketika berkomunikasi di media sosial, perwakilan perusahaan dipaksa untuk menjadi terintegrasi ke dalam arus komunikasi perusahaan perusahaan, dan untuk mematuhi strategi komunikasi perusahaan perusahaan. Tujuan dan minat perusahaan memiliki dampak pada semua elemen proses, sehingga menjadikan proses komunikasi bermakna menurut sudut pandang perusahaan. Ini mencerminkan Argenti (2006) dan Posisi Grunig (2009), serta Bruhn (2008), dan Van Riel (Kazaka. 2013), di mana peran utama dianggap berasal dari komunikasi strategis, yang telah diselaraskan dengan tujuan keseluruhan perusahaan. Di sisi lain, dalam perusahaan media sosial berada di bawah tekanan dari komunitas pengguna yang kritis dalam sikap mereka terhadap komersialisasi lingkungan media sosial, enggan menerima perusahaan, segera mendistribusikan informasi skandal yang berkaitan dengan perusahaan.

Tekanan ini juga disebabkan oleh konten yang dibuat pengguna yang dapat 
dibuat kapan saja dan didistribusikan di media sosial apa pun. Jika itu memengaruhi perusahaan, itu menciptakan tekanan tambahan. Media sosial dicirikan oleh fakta bahwa perusahaan tidak hanya tentang target audiens perusahaan, tetapi juga tentang komunitas yang mempengaruhi target audiens ini. Ini menjelaskan arti dari konsep pemangku kepentingan Cornelissen (2009:15), ketika tidak hanya pelanggan potensial atau potensial yang dihitung, tetapi juga yang dapat memengaruhi perusahaan. Ini berarti bahwa perwakilan perusahaan, yang berkomunikasi di media sosial atas nama perusahaan atau merek, harus selalu mempertimbangkan dua sumber tekanan, karena mengabaikan salah satu dari perusahaan dapat menyebabkan masalah bagi perusahaan: apakah komunikasi tidak akan sesuai dengan kepentingan perusahaan lagi atau itu akan menyebabkan ketidaksenangan pengguna.

Nilai tambah adalah elemen utama dalam model yang diusulkan. Berdasarkan hasil penelitian, kriteria nilai tambah berikut ditetapkan: 1) Memberikan konsultasi atau rekomendasi praktis kepada pengguna di profil media sosial; 2) Ketersediaan ahli perusahaan / organisasi untuk komunikasi di media sosial; 3) Menanggapi pertanyaan atau kritik yang dipublikasikan dalam profil media sosial perusahaan; 4) Menanggapi pertanyaan atau kritik yang dipublikasikan di profil pengguna; 5) Menerbitkan informasi yang menarik bagi pengguna, tetapi tidak terkait langsung dengan aktivitas perusahaan / organisasi; 6) Menyediakan layanan di profil media sosial; memberikan bonus kepada pengguna media sosial.

Dalam pelaksanaanya kegiatan komunikasi korporat di Sari Ater Hotel \& Resort dalam menghadapi revolusi industri 4.0 terbagi menjadi dua, yaitu komunikasi internal dan komunikasi eksternal dimana terdapat interaksi dalam bidang pekerjaan antar departeman dan adanya saling ketergantungan antar karyawan melalui komunikasi, karena hanya dengan komunikasi pengaruh atas perilaku individu atau karyawan dapat terjadi. Interaksi yang terjadi bukan hanya internal saja, tetapi juga bagaimana berkomunikasi dengan publik eksternal, seperti misalnya, membina hubungan dengan pemerintah atau konsumen. Jadi semua kegiatan, termasuk proses MSDM sangat menentukan kelangsungan hidup organisasi, tergantung komunikasi efektif yang diterapkan oleh Sari Ater Hotel \& Resort sehingga penyelenggaraan sistem komunikasi efektif dapat berlangsung dengan efektif, terutama bagaimana memetakan arah informasi yang mengalir dalam suatu organisasi baik ke dalam (internal public) mau pun ke luar (external public) peran MSDM yang berkualitas dalam rangka meningkatkan kinerja karyawan merupakan faktor yang sangat penting.

Berkaitan dengan uraian di atas, hasil penelitian yang dilakukan oleh Ruliana (2012:87) menunjukkan bahwa faktor komunikasi internal berperan penting dalam menciptakan sistem komunikasi yang efektif, selain itu komunikasi internal dapat mempengaruhi proses komunikasi 
yang dilakukan ke publik/khalayak yang dijadikan sasaran. Kinerja karyawan tidak hanya ditentukan dengan menggunakan sistem teknologi canggih, tetapi pendekatan komunikasi organisasi efektif yang sifatnya sirkuler jauh lebih penting karena dapat mengetahui secara langsung bagaimana motivasi, sikap mental dan perubahan perilaku seorang karyawan adalah sangat menentukan dan sangat mendukung untuk mencapai suatu prestasi, begitu juga kinerja karyawan dapat dilihat bagaimana kuantitas dan kualitas output, efektif, efisien serta menimbulkan kepuasan kerja bagi kerja karyawan yang didasarkan pada penilaian yang sudah ditetantukan sebelumnya. Temuan menunjukkan bahwa komunikasi yang efektif merupakan persyaratan utama pelaksanaan yang efektif tetapi tidak menjamin efektivitas. Maka dalam . studi komunikasi keorganisasian menurut Hardjana (dalam Ruliana, 2014) terdapat sebuah asumsi yang menyatakan bahwa tidak ada suatu sistem komunikasi yang dapat bekerja efektif sepanjang zaman, dalam sejarah organisasi tanpa pernah mengalami perubahan dan penyesuaian. Hal ini terjadi karena pengaruh lingkungan eksternal yang mempengaruhi jalannya suatu organisasi.

Perkembangan komunikasi korporat Sari Ater Hotel \& Resort juga dipengaruhi perkembanganr revolusi industri 4.0. Komunikasi korporat Sari Ater Hotel \& Resort menunjukkan pemenuhan tujuan organisasi yaitu mengembangkan perspektif komunikasi perusahaan, tidak memerlukan membangun fungsi baru dalam organisasi”" (Van Riel, 2010), Argenti
2010), Cornelissen (2009). Komunikasi korporat dapat didefinisikan sebagai:

"pendekatan terpadu untuk semua komunikasi yang dihasilkan oleh suatu organisasi, diarahkan pada kelompok sasaran yang relevan" (Van Riel, 1995: 24),

baik internal maupun eksternal. Model komunikasi korporat terkait perkembangan revolusi industry, misalnya, dimana pertama kali ditemukannya mesin-mesin yang dapat membantu pekerjaan manusia. Pada tahap tersebut, dalam bidang komunikasi mesin yang pertama kali digunakan ialah mesin pencetak koran untuk penyebaran informasi secara massal. Saat itulah pertama kali terjadinya komunikasi jarak jauh, secara massal, walaupun tanpa adanya feedback dari komunikan karena masih bersifat linier. Saat ini telah terjadi perubahan komunikasi di era industri 4.0 telah terjadi perubahan dalam model komunikasi, seperti terlihat dalam gambar 3 .

Revolusi industri menyebabkan serangkaian industri dan peningkatan persaingan di antara perusahaan dan faktor ekonomi global yang keras juga menyebabkan pemikiran ulang tentang strategi komunikasi korporat baru bagi perusahaan (Cornellisen, 2004). Penelitian tentang strategi komunikasi korporat juga dilakukan oleh Juwita, Rina (2017: 47-60) yang mengatakan bahwa :

"Kemajuan media interaktif digital telah membawa struktur komunikasi baru sehingga penting bagi para praktisi dan akademisi komunikasi korporat untuk memahami perubahan yang disebabkan oleh perkembangan tersebut. Bersatunya komunikasi dan teknologi menawarkan praktisi PR peluang untuk membentuk kinerja ke arah yang lebih strategis."

Demikian juga yang dikemukakan oleh Aavani Desai, (2018) bahwa pesatnya 

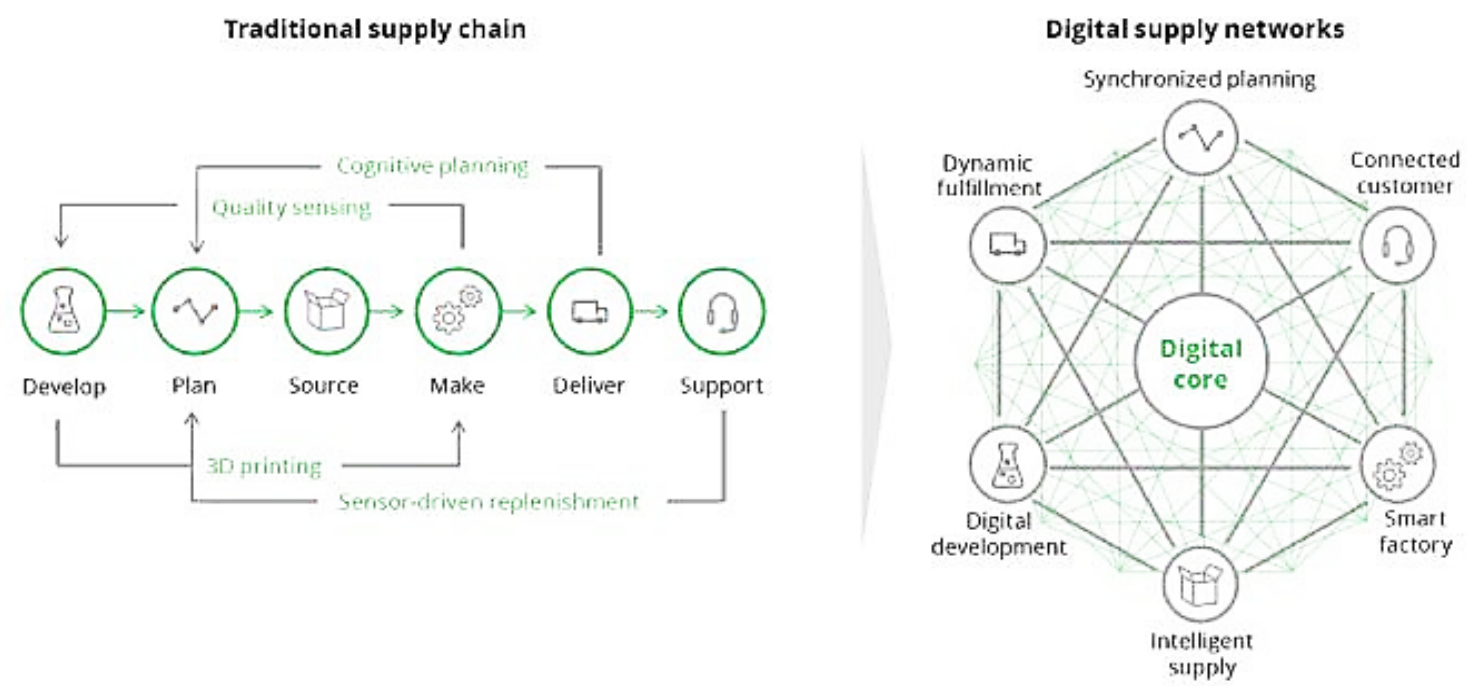

Gambar 3. Model Komunikasi di Era Revolusi Industri 4.0

Sumber : Deloitte dalam Subagyo, 2018

perkembangan media digital telah menyebabkan akademisi dan praktisi untuk meningkatkan keterlibatan interaktif mereka dengan banyak pemangku kepentingan.

Penelitian ini, membahas model komunikasi korporat yang menyesuaikan berbagai praktik komunikasi menggunakan kemajuan teknologi, seperti penggunaan media sosial. Media sosial dinilai lebih efektif dalam menyampaikan berbagai program pelayanan komunikasi dari perusahaan kepada para klien. Perubahan model komunikasi dari linier ke sirkuler, jika dikaitkan dengan penggunaan model PR memiliki keterkaitan. Grunig and Todd (Ruliana, 2016) menerbitkan Empat Model, seperti tampak gambar 4.

Model pertama adalah publisitas, kedua dikenal sebagai model public relations informasi, ke dua, persuasi asimetris ke tiga, dan yang terakhir model simetris dua arah adalah definisi formal dari praktek terbaik public relations. Model
Grunig tetap relevan sampai hari ini sepert ketika pertama kali diciptakan hampir 30 tahun yang lalu. Selanjutnya Grunig menunjukkan penggunaan empat model PR. yang diaplikasikan dalam kegiatan PR dengan menggunakan media digital saat ini, Grunig dan Hunt (dalam Ruliana, 2016) optimis bahwa:

"Meskipun banyak praktisi hanya memindahkan keterampilan dan teknik hubungan media mereka ke media digital, daya tarik baru dengan media sosial menjanjikan konsekuensi positif bagi profesi PR."

Media digital ini menurut keduanya dapat digunakan untuk: 1) Komunikasi dua arah interaktif dan dialogis dengan para pemangku kepentingan (organisasi media, karyawan, lembaga keuangan, regulator dll); 2) Penelitian pemindaian lingkungan dan identifikasi masalah, publik, dan masalah (pemantauan media); 3) Segmentasi pemangku kepentingan dan publik; 4) Masalah dan krisis program komunikasi; 5) Mengukur jenis dan kualitas hubungan yang dikembangkan dengan publik, kognisi, sikap, dan perilaku. 


\begin{tabular}{|c|c|c|}
\hline Model Name & $\begin{array}{l}\text { Type of } \\
\text { Communication }\end{array}$ & Characteristics \\
\hline $\begin{array}{l}\text { Press agent / } \\
\text { publicity }\end{array}$ & $\begin{array}{l}\text { One-way } \\
\text { communication }\end{array}$ & $\begin{array}{l}\text { Uses persuasion and manipulation to influence audiences } \\
\text { to behave as the organisation desires. }\end{array}$ \\
\hline $\begin{array}{l}\text { Public information } \\
\text { model }\end{array}$ & $\begin{array}{l}\text { One-way } \\
\text { communication }\end{array}$ & $\begin{array}{l}\text { Uses press releases and other one-way communication } \\
\text { techniques to distribute organisational information. The } \\
\text { public relations practitioner is often referred to as the in- } \\
\text { house journalist. }\end{array}$ \\
\hline $\begin{array}{l}\text { Two-way } \\
\text { asymmetrical model }\end{array}$ & $\begin{array}{l}\text { Two-way } \\
\text { communication } \\
\text { (imbalanced) }\end{array}$ & $\begin{array}{l}\text { Uses persuasion and manipulation to influence audiences } \\
\text { to behave as the organisation desires. Does not use } \\
\text { research to find out how stakeholders feel about the } \\
\text { organisation. }\end{array}$ \\
\hline $\begin{array}{l}\text { Two-way symmetrical } \\
\text { model }\end{array}$ & $\begin{array}{l}\text { Two-way } \\
\text { communication }\end{array}$ & $\begin{array}{l}\text { Uses communication to negotiate with the public, resolve } \\
\text { conflict and promote mutual understanding and respect } \\
\text { between the organisation and its stakeholders }\end{array}$ \\
\hline
\end{tabular}

Gambar 4. Empat Model Komunikasi

Sumber : Grunig (Ruliana, 2016)

Grunig dan Hunt menggambarkan korporat, peran manajemen sumber daya bagaimana penggunaan empat model (MSDM) sangat penting dan masih tetap perkembangan PR dalam gambar 5.

Sari Ater Hotel \& Resort sebagai sebuah perusahaan sekaligus bagian dari industri 4.0, penting untuk merancang model komunikasi korporat untuk menjaga citra dan reputasi perusahaan dimata publik, baik publik internal dan publik eksternal. Untuk mengoptimalkan aktivitas komunikasi menjadi pusat perhatian dan tumpuan bagi suatu organisasi perhotelan untuk dapat bertahan di era globalisasi yang diiringi dengan tingkat persaingan yang semakin ketat. Watson, D'Annunzio Green dan Maxwell (2005) melaporkan temuan dari sejumlah studi yang menemukan bahwa yang paling penting masalah yang dihadapi

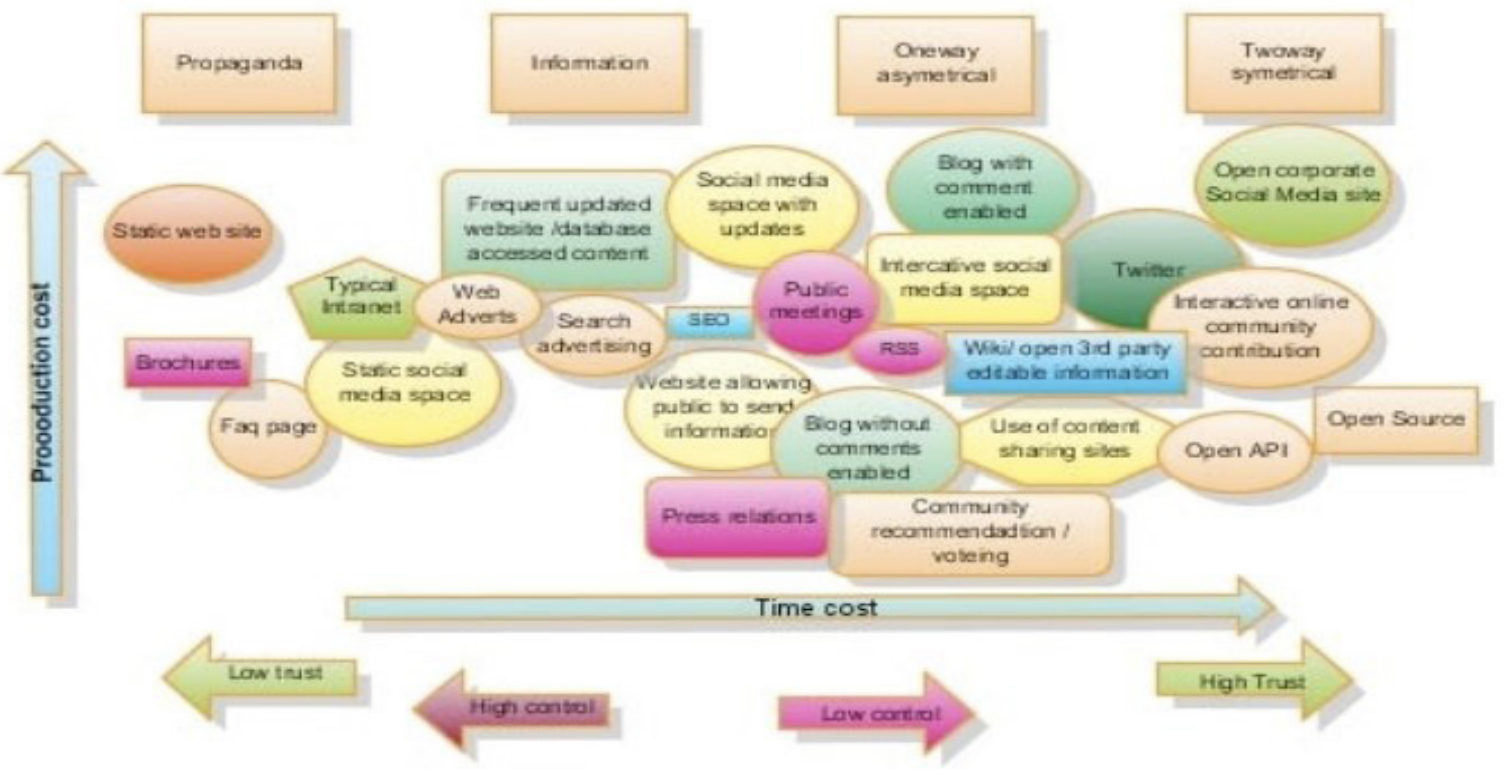

Gambar 5. Penggunaan Empat Model Perkembangan Public Relations

Sumber : Grunig (Ruliana, 2016) 
perhotelan adalah MSDM yang berkaitan dengan kualitas pelayanan, pelatihan keterampilan komunikasi karyawan, perekrutan staf dan seleksi. Hal ini sesuai dengan yang dikemukakan oleh Ahles (1991, dalam Ruliana, 2016) bahwa hotel mengembangkan keterampilan komunikasi karyawan dengan mengukur efektivitas komunikasi melalui survei dan penilaian kinerja. Dengan komunikasi internal yang efektif, industri perhotelan bersinar dalam kemampuannya untuk membawa merek ke audiens internal dan eksternal.Hasil temuan lain ditemukan bahwa isu masa depan MSDM yang dihadapi perhotelan adalah sikap komitmen yang dimiliki para karyawan, pelatihan dan pengembangan, kualitas layanan, perekrutan staf dan seleksi, membangun team (team building) kerja sebagai persiapan dalam menghadapi era digital. Dengan membangun kepercayaan publik yang cukup besar dapat memberikan efek posisitif bagi kelanjutan usaha sebuah perusahaan, model komunikasi berperan penting. Tujuan penulisan ini adalah untuk menemukan model komunikasi perusahaan Sari Ater Hotel \& Resort dalam menghadapi revolusi industri 4.0.

\section{Metode Penelitian}

Penelitian ini menggunakan kualitatif dengan menggunakan metode deskriptif. Pengumpulan data menggunakan metode observasi, yaitu mengobservasi tentang kegiatan perusahaan Sari Ater Hotel \& Resort dalam merencanakan dan mengimplementasikan strategi korporat menghadapi revolusi 4.0. Studi dokumentasi dilakukan pada dokumen- dokumen yang berkaitan dengan programprogram komunikasi korporat dan PR dalam menghadapi revolusi industry 4.0 dan studi kepustakaan. Analisis literatur atau studi pustaka digunakan sebagai teknik pengumpulan data. Metode ini menurut Diana Ridley (2012) merupakan suatu cara mengidentifikasi teori dan penelitian sebelumnya yang sudah ada, yang dapat memengaruhi pilihan topik penelitian dan metode yang digunakan. Sumber data tersebut berupa kajian-kajian ilmiah yang telah diteliti sebelumnya yaitu buku komunikasi korporat, jurnal komunikasi yang relevan dengan penelitian, dan laporan kegiatan perusahaan dan internet yang berkaitan dengan model komunikasi korporat dalam menghadapi revolusi industri 4.0. Teknik analisis data yang digunakan dalam penelitian ini yaitu meliputi aktivitas pengumpulan data, data reduction (reduksi data), data display (penyajian data), dan conclusion drawing atau penarikan kesimpulan/verifikasi.

\section{Hasil Penelitian dan Pembahasan}

Dalam membahas hasil penelitian, penulis mencoba mengaplikasikannya ke dalam model nilai tambah (value added model) yang mencerminkan proses komunikasi korporat di media sosial. Model ini mencakup elemen-elemen berikut: mendengarkan, pesan, pilihan media sosial, tingkat personifikasi, interaksi, nilai tambah, tekanan komunitas, tekanan strategi Ada pun pembahasannya sebagai berikut:

\section{Mendengarkan}

Pada tahap mendengarkan pihak Sari Ater Hotel \& Resort yang diwakili oleh 
Marketing PR adalah sebagai berikut

Mendengarkan keingin dan kebutuhan para stakeholder yang berkaitan dengan produk dan jasa yang dihasilkan perusahaan sangat penting, terutama untuk mempromosikan, baik secara langsung melalui komunikasi interpersonal maupun tidak langsung dengan membuat laman di media sosial/online seperti ulasan yang diberikan para wisatawan domestik terhadap fasilitas yang kami tawarkan kepada para tamu yang menginap atau tidak, baik wisatawan domestik maupun wisatawan mancanegara, ulasannya ada yang positif dan negatif (wawancara, 1 April 2019).

Ulasan yang dikemukakan wisatawan pihak Sari Ater Hotel \& Resort bekerjasama dengan booking.com sehingga dapat diketahui puas atau tidaknya pelayanan yang diberikan, adapun ulasannya seperti gambar 6.

Gambar 6 merupakan sarana interaktif atau timbal balik yang disediakan oleh Sari Ater Hotel \& Resort bekerjasama dengan booking.com. Beragam ulasan yang dikemukakan wisatawan terhadap pelayanan dan fasilitas yang diberikan Sari Ater Hotel \& Resort dapat dikatakan baik, walaupun ada yang baik pendapatnya tetapi hal ini dapat dijadikan bahan masukan bagi manajemen Sari Ater Hotel \& Resort Hal ini sesuai dengan penelitian yang dilakukan Tamar
Ashuri, Shira Dvir-Gvisman, Ruth Halperi (2018), mengungkapkan informasi di situs jejaring sosial berfokus pada sifat timbal balik dari situs-situs tersebut, penelitian ini mengeksplorasi peran penting pembelajaran observasional dalam menentukan kesediaan pengguna untuk mengungkapkan informasi sendiri di Facebook dan ini menunjukkan bagaimana kemampuan untuk melihat tindakan pengguna lain.

\section{Pesan}

Pesan yang disampaikan oleh perusahaan, dalam hal ini manajer PR sebagai komunikator yang mewakili Sari Ater Hotel \& Resort atau pejabat lainnya seperti Director of Sales dan Marketing Manager menggunakan bahasa yang mudah dimengerti dan memiliki daya tarik ketika membaca pesan atau informasi yang diberikan kepada pihak wisatawan sebagai komunikan yang dijadikan sasaran. Bahasa yang digunakan di media sosial adalah Bahasa Indonesia dan Bahasa Inggris untuk menawarkan semua jenis produk dan jasa yang ditawarkan dengan kelebihan dan kekurangan dari masing-masing produk dan
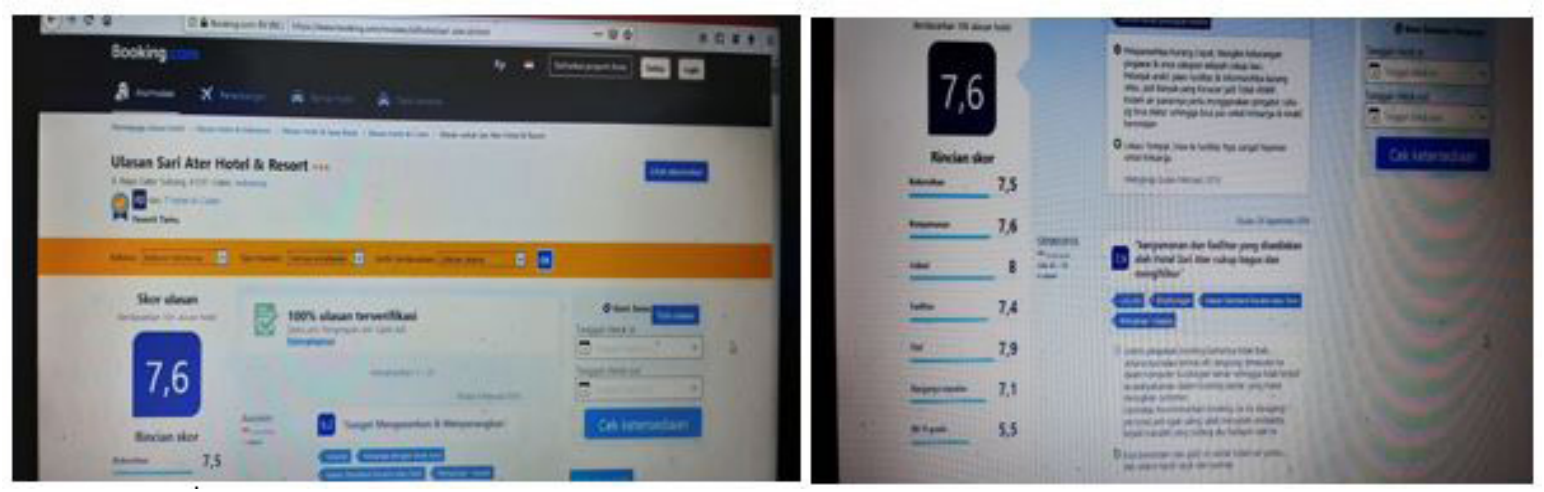

Gambar 6. Kepuasan Pelayanan melalui booking.com

Sumber: booking.com, 2019 
jasa sehingga pilihan ada pada khalayak (Gambar 7). Dalam wawancara dengan Manager PR (2 April, 2019) dikemukakan bahwa:

Pemilihan bahasa dalam menyampakan pesan/ informasi merupakan factor yang sangat penting apalagi ke wisatawan yang datang tidak hanya wisatawan dari dalam negeri, tepai juga dari luar negeri, seperti dari Saudi Arabia, Inggris, Kanada, Jepang. Jadi bahasa yang kami gunakan adalah Bahasa Indonesia dan Bahasa Inggris. Isi Pesan dirumuskan terlebih dahulu secara informatif dan edukatif agar dapat dipahami dan menimbulkan daya tarik baik secara visual.

Perumusan pesan secara terstruktur tersebut penting sekali mengingat pengguna internet tidak hanya berunteraksi dengan perusahan Sari Ater Hotel \& Resort tetapi juga dengan yang lain. Piligrimiene, (2013) mengemukakan bahwa:

Media sosial mengubah model komunikasi oneto-many menjadi model many to many, oleh karena itu konsumen dapat menjawab pesan perusahaan Selain itu, audiens di media sosial berinteraksi tidak hanya dengan perusahaan, tetapi juga di antara mereka sendiri Karena itu, ketika merencanakan komunikasi di media sosial, penting untuk menjawab pertanyaan: bagaimana interaksi audiens dengan konten akan dipastikan (yang diungkapkan melalui pembuatan konten, membagikannya, bertukar, berkomentar, menerbitkan, mengendalikan, kritik dan evaluasi); dan bagaimana audiens akan saling mempengaruhi.

\section{Pilihan Media Sosial}

Kesiapan dalam menghadapi revolusi industry 4.0 pilihan media sosial sangat penting untuk menyampaikan pesan kepada publik yang dijadikan sasaran, karena media sosial menggabungkan antara proses fisik dan komputasi teknologi (Prasetyo \& Sutopo, 2018). Penyusunan strategi pemilihan media sosial atau saluran komunikasi didasarkan pada pertimbangan luasnya jangkauan media sehingga dapat diterima oleh publik yang dijadikan sasaran. Dari hasil wawancara diperoleh informasi dari Marketing Manager PR bahwa:

Menggunakan media digital seperti Website dan jugamembuat laman Sari Ater Hotel \& Resort di Facebook, Google Plus, Twitter, Instagram dan Linkeldn dimana masing-masing media sosial ini memiliki pengaruh yang berbeda terhadap pesan yang disampaikan. Untuk menyeimbangkan informasi, digunakan juga media konvensional, seperti radio dan press release (wawancara, 1 April 2019).

Salah satu contoh media yang digunakan oleh Sari Ater Hotel \& Resort dalam menghadapi revolusi industry 4.0 adalah dengan membuat laman atau situs website, www.sariater.com dan www.sariater.co.id . seperti terlihat dalam gambar 8 .
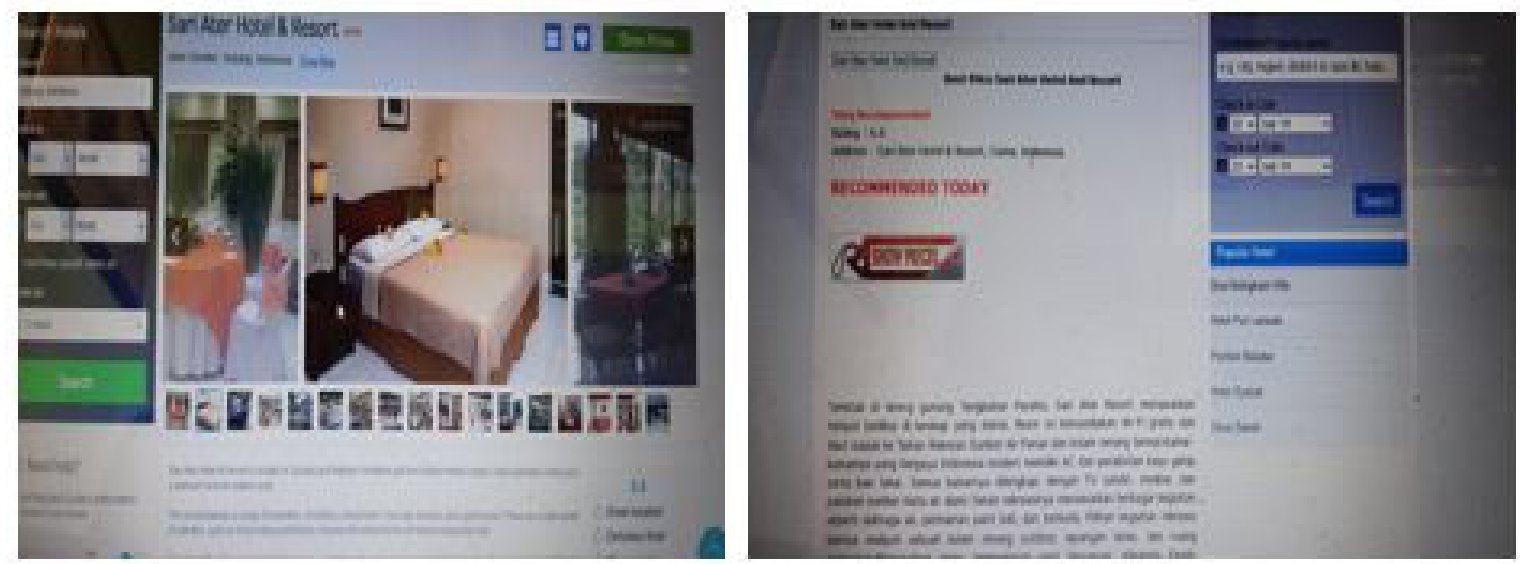

Gambar 7. Informasi Pilihan Bahasa di booking.com

Sumber: tripadvisor co.id, 2018 
Hasil penelitian yang dilakukan Ruliana dan Dwiantari (2009), menggambarkan bahwa PR dalam menyampaikan pesannya menggabungkan media konvensional dan media digital. Gabungan media ini dimaksudkan untuk mempromosikan produk dan jasa secara lebih luas, tetapi tidak hanya promosi saja, tetapi juga memberikan respon terhadap opini yang diberikan pengunjung. Demikian juga penelitian yang dilakukan O Kazaka (2011) menemukan bahwa peran media konvensional (pers, televisi, radio) dalam komunikasi perusahaan masih cukup besar sehingga disarankan untuk memasukkan media sosial dalam strategi komunikasi keseluruhan menggunakan keduanya. media konvensional dan sosial dalam mencapai tujuan. Hal ini sesuai dengan yang dikemukakan oleh Manager PR

"PR sebagai pembuka jalan, melalui media-media,baik cetak, misalnya majalah dan elektronik, seperti radio dan televisi dengan membuat press release, pameran-pameran, news letter yang berisikan inovatif dari produk Sari Ater. Facebook, instragram, Twitter, website dan lain-lain juga merupakan media yang digunakan oleh Sari Ater."

Bentuk lainnya dari media yang digunakan adalah majalah dinding (madding) seperti yang dikemukakan Manager PR berikut ini:

"Digunakan juga melalui penempatan madding, baik untuk informasi internal dan eksternal, yang berisi kegiatan-kegiatan yang telah dilakukan Sari Ater, foto-foto dari pengunjung (pejabat, perusahaan-perusahaan bahkan para celebrity) yang datang dan menginap di Sari Ater Hotel \& Resort." (Wawancara, 1 April, 2019)

Jika disimak hasil wawancara tersebut, menggambarkan lingkup media yang digunakan oleh PR Manager Sari Ater Hotel \& Resort untuk mempromosikan produk dan jasa. Seperti above the line, yaitu media elektronik, seperti radio, tv dan surat kabar melalui press release dan membuat website, Facebook di internet. Di samping itu, menggunakan below the line, park melalui kegiatan pameran, membuat news letter dan memasang pengumuman dan majalah dinding agar dibaca oleh para karyawan dan para pengunjung atau tamu yang datang menginap. Startegi pemilihan media yang dilakukan oleh PR Manager Sari Ater Hotel $\&$ Resort dapat dikatakan sudah tepat dalam mempromosikan produk dan jasa sehingga dapat menimbulkan daya tarik bagi para pengunjung atau pun public umumnya untuk datang mengunjungi Sari Ater Hotel \&

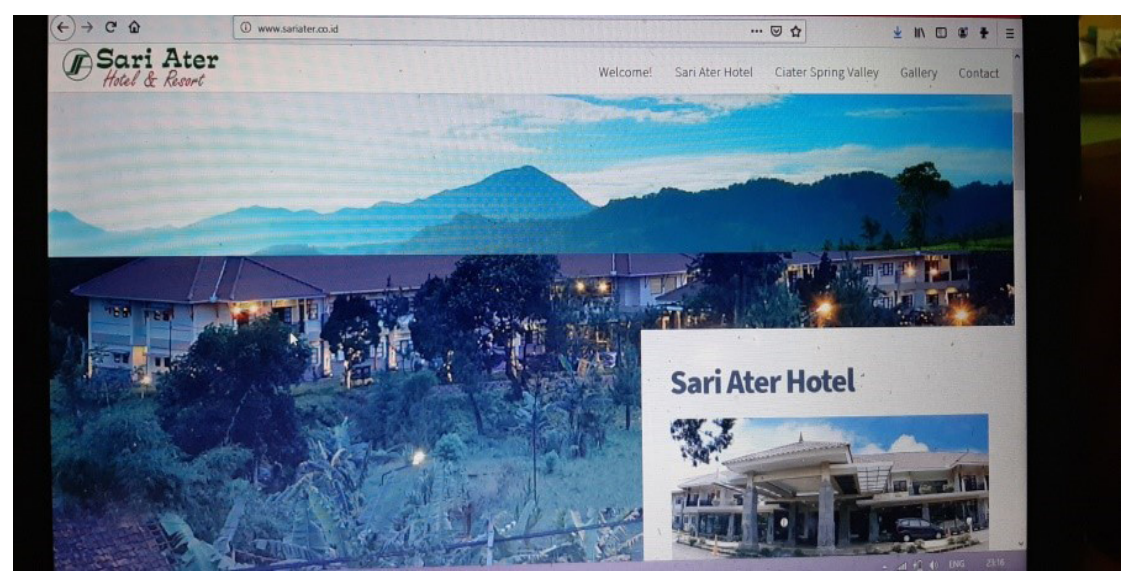

Gambar 8. Media Sosial Sari Ater Hotel \& Resort

Sumber: www.sariater.co.id, 2019 
Resort dan obyek rekreasi dilengkapi sarana yang memadai.

Alat atau media komunikasi eksternal tersebut digunakan oleh Sari Ater Hotel \& Resort sebagai media hubungan komunikasi korporat Sari Ater Hotel \& Resort dalam upaya penyampaian pesan-pesan, informasi, dan berita (bentuk tulisan atau photo release) perusahan; manfaat produk/jasa dan publikasi lainnya yang ditujukan kepada para konsumen, pelanggan, distributor, suplier, relasi bisnis, stakeholder (hubungan dengan pihak terkait), stock holder (hubungan dengan pemilik) dan employee relations (hubungan dengan karyawan)

\section{Tingkat Personifikasi}

Keputusan yang diambil oleh suatu perusahaan dalam pemilihan media sangta penting, karena personifikasi dapat mengidentifikasi hubungan pengguna dengan perusahaan atau secara anonim. Internet dan media sosial tertentu memberikan peluang untuk mempublikasikan informasi baik secara pribadi dalam profil perusahaan resmi di jejaring sosial dan di blog. Perusahaan secara personfikasi tidak membangun informasi secara pribadi, namun perusahaan mempublikasikan baik informasi-informasi produk dan jasa yang ditawarkan dengan menggunakan strategi komunikasi pemasaran atau pun berita-berita yang disusun oleh PR sehingga peran PR sangat menonjol karena berperan sebagai fasilitator komunikasi korporat dalam menciptakan citra perusahaan.

Menurut Marketing Manager Sari Ater Hotel \& Resort, personifikasi dibangun untuk meningkatkan citra perusahaan (image corporate) melalui komunikasi internal dan komunikasi eksternal dengan memanfaatkan media digital di era revolusi 4.0 ini. Komunikasi internal dibangun melalui morning brifing, rapat direksi, program pelatihan keterampilan komunikasi (skill of communication), program peningkatan kinerja kerja karyawan sebagai persiapan dalam menghadapi revolusi industri 4.0 diselenggarakan pelatihan bahasa inggris, Komunikasi eksternal dilakukan dengan membina hubungan dengan stakeholder, seperti pemerintah, investor dan lain-lain seperti yang pada gambar 9 .

Produksi melihat perusahaan menerima hanya input, proses dan output. Menurut Freeman (Kalle Pajunen 2011) model stakeholder memberikan visualisasi yang kuat dalam hubungan multilateral yang lebih realistis. Agar lebih jelasnya berikut gambar menurut Freeman yang mengelompokkan stakeholder menjadi beberapa bagian, berdasarkan hubungannya dengan perusahaan. Pada gambar berikut, Freeman menjelaskan tentang pembagian stakeholder berdasarkan tingkatan atau lapisan terdalam sampai dengan lapisan terluar perusahaan atau Internal sampai dengan Eksternal Perusahaan.

Pada gambar pemetaan (Gambar 9) stakeholder diatas dapat dilihat perusahaan memiliki hubungan yang signifikan dengan setiap lapisan masyarakat, lapisan yang paling dekat dari hubungan yang harus dibuat dengan perusahaan pada gambaran ini adalah pemilik perusahaan sedangkan lapisan terluar adalah lembaga profesi, media publik masa depan dan komunitas 


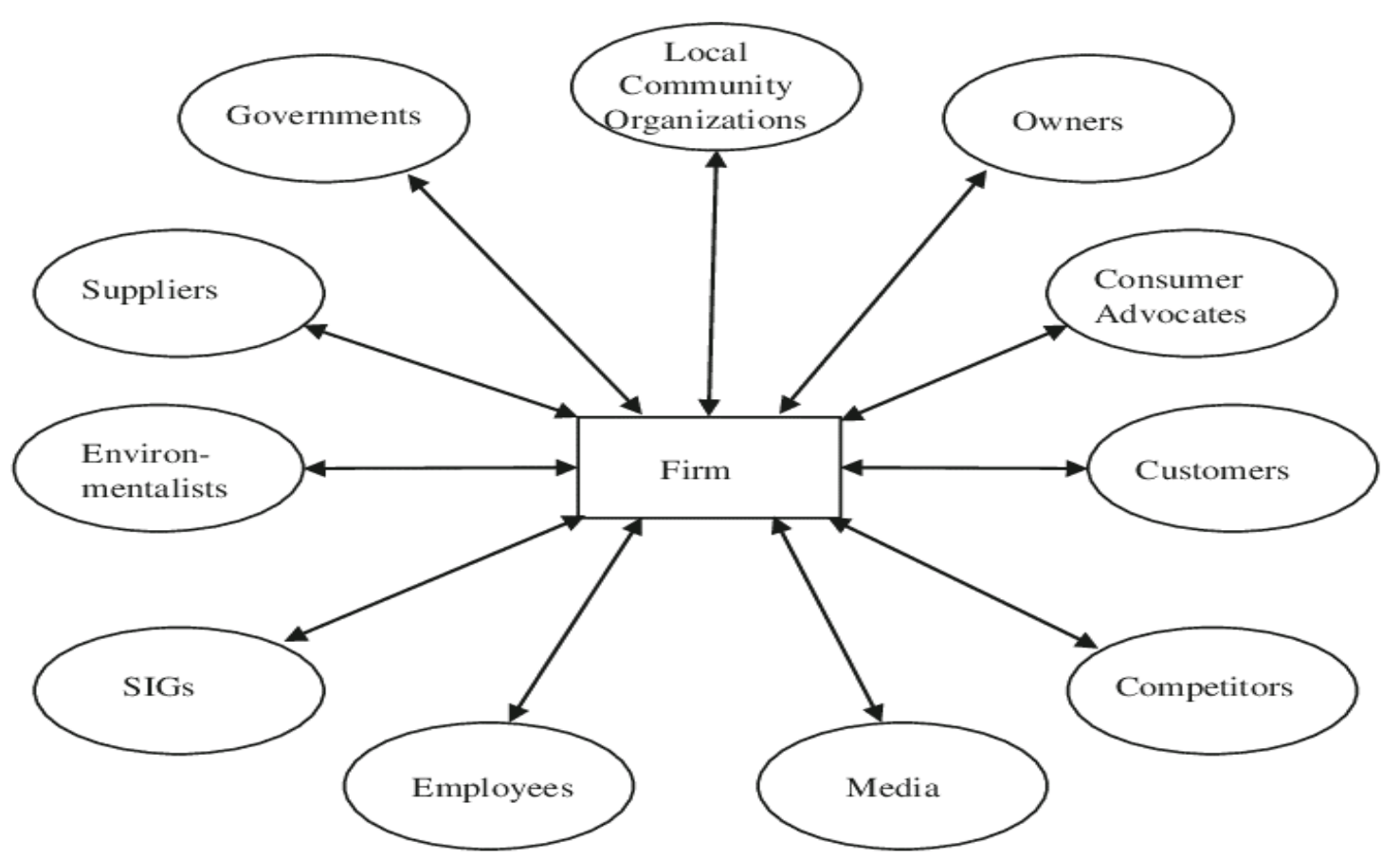

Gambar 9. Pandangan Pemangku Kepentingan tentang Perusahaan

Sumber: Freeman, dalam Kelle Panjunan, 2011

global dan komunitas lingkungan. Asumsi

pentingnya hubungan dan keterkoneksian dengan stakeholder ini tidak sama tiap perusahaan, biasanya disesuaikan dnegan jenis industrinya, begitu pula dengan perusahaan Sari Ater Hotel \& Resort.

Gambar 9 mendeskripsikan bagaimana proses komunikasi korporat yang dilakukan oleh Sari ater Hotel \& Resort dengan stakeholder yang terbagi menjadi dua bagian kegiatan komunikasi korporat yang dilaksanakan, yaitu komunikasi internal dan komunikasi eksternal. Komunikasi internal terdiri dari pemilik/pemegang saham, Top manajemen atau direksi, karyawan dan keluarga karyawan. Kemudian komunikasi eksternal yang terdiri dari pemerintah, pemasok, asosiasi bisnis, media/pers, konsumen dan kelompok interes khusus. Untuk mewujudkan kegiatan komunikasi tersebut diperlukan suatu model komunikasi komunikasi yang dapat dilakukan secara bertahap sesuai dengan program kerja masing-masing divisi terutama dalam menghadapi revolusi industri 4.0.

\section{Interaksi}

Terkait hubungan (relationship), hubungan adalah sistem komunikasi yang dibangun, dipelihara, dan berubah sepanjang waktu oleh interaksi. Interaksi bukan sekadar pertukaran informasi, setiap pesan memiliki implikasi konten dan hubungan. Dalam hubungan, ada pola dan dimensi kontrol, seperti dominasi, submisi, dan keseimbangan. Terkait jaringan komunikasi, organisasi dan struktur sosial lainnya berasal dari interaksi antar individu atau kelompok, yang terdiri dari respon individu/kelompok atas perilaku individu/kelompok lain. Individu adalah bagian dari kelompok yang saling berkomunikasi dengan kelompok lain membentuk sistem yang lebih besar yang dapat dilakukan melalui komunikasi 
antarpribadi dan komunikasi kelompok melalui media sosial, seperti Facebook dirasakan manfaatnya oleh Sari Ater Hotel \& Resort.

Kepala Dinas Pariwisata Pemuda dan Olahraga Kabupaten Subang, Ahmad Sobari mengatakan bahwa Sari Ater hingga saat ini masih merupakan salah satu daya tarik terbesar wisatawan untuk berkunjung ke Subang. salah satu kunci utama dalam promosi pariwisata adalah peran media, karenanya dirinya sangat mengapresiasi kegiatan interaksi silaturahmi dengan media yang dilakukan Sari Ater (web KotaSubang. com, 2018).

Interaksi yang dibangun oleh pihak Sari Ater Hotel \& Resort, salah satuya adalah membina hubungan dengan individu atau organisasi pemerintahan, dan juga membina hubungan dengan media konvensional dan media digital. Dalam studi terbaru, misalnya, Chang dan Chen (2014) dan Chang dan Heo (2014) menawarkan skala rumit yang mengukur manfaat yang dirasakan dengan menggunakan barang-barang seperti:

"Saya merasa bahwa Facebook membantu saya berinteraksi dengan teman-teman."

Namun demikian, penulis tidak mengukur persepsi pentingnya interaksi dengan teman melalui Facebook. Sebagai gantinya, tampak bahwa penelitian ini mengadopsi pandangan normatif yang menurutnya ikatan sosial secara universal penting. Mengabaikan perbedaan di antara pengguna terkait dengan signifikansi keuntungan (dan kerugian) spesifik, menghasilkan estimasi yang tidak tepat dari kalkulus privasi individu masing-masing pengguna. Kelemahan yang sama muncul sehubungan dengan perbedaan di antara skenario. Misalnya, walaupun dibajak jelas merupakan situasi yang mengkhawatirkan, kemungkinannya jauh lebih kecil daripada menerima komentar dari teman. Dengan berkonsentrasi pada besarnya saja, kami mengambil risiko kesalahan penilaian dari pengguna yang dirasa mengalami kerugian yang menganggap kedua skenario ini mengungkapkan informasi di situs jejaring sosial (SNS). Berfokus pada sifat timbal balik dari situs-situs tersebut, penelitian ini mengeksplorasi peran penting pembelajaran observasional (OL) dalam menentukan kesediaan pengguna untuk mengungkapkan informasi sendiri di Facebook. Namun, di era digital saat ini, keterlibatan antara publik dan organisasi adalah salah satu karakteristik utama internet (Colleoni, 2013). Banyak situs web perusahaan sudah memiliki tingkat interaktivitas yang tinggi; termasuk kemampuan mereka untuk menyebarluaskan informasi dan untuk menghasilkan hubungan antara berbagai publik dan organisasi (Capriotti \& Moreno, 2007). Pada pendekatan pertama, tingkat interaktivitas rendah, dan penggunaan Internet adalah searah; karena tujuan utamanya adalah untuk menyebarkan informasi dan mencoba meningkatkan citra perusahaan dalam bisnis. Namun, dalam pendekatan kedua, tingkat interaktivitasnya tinggi, dan Internet digunakan untuk memfasilitasi komunikasi dua arah dan untuk memelihara hubungan dengan memungkinkan dialog dan interaksi antara organisasi dan para pemangku kepentingannya (web sustantia mea, 2019). 
Berkaitan dengan uraian di atas Fieseler \& Fleck (web substantia mer, 2019) mengemukakan bahwa komunikasi interaktif yang dilakukan oleh Sari Ater Hotel \& Resort menjadi salah satu saluran informasi paling penting bagi perusahaan karena perubahan dinamika sosial. Kerjasama berbasis web dan pertukaran data telah memberdayakan komunikasi antara bisnis dan para pemangku kepentingan. Buhalis \& Law dan O'Riley serta Fieseler (web sustantia mea, 2019) menyatakan ini memungkinkan untuk terlibat dengan pengguna online dan memanfaatkan publisitas positif yang muncul dari pemasaran dari mulut ke mulut dan platform digital. Perusahaan dapat mempertahankan legitimasi dengan lebih baik karena mereka terlibat dengan pemangku kepentingan melalui media sosial; dan mengambil fungsi menjaga gerbang media tradisional.

\section{Nilai Tambah}

Proses komunikasi Sari Ater Hotel \& Resort adalah adalah komunikasi internal dan komunikasi eksternal yang mencerminkan identitas, citra dan reputasi perusahaan. Objek rekreasi adalah sarana pendukung yang dimiliki Sari Ater Hotel \& Resort. Objek rekreasi wisata yang paling dikenal adalah sumber daya air panas alam yang memiliki khasiat untuk menyembuhkan berbagai penyakit yang memberikan nilai tambah karena menggambarkan posisi hotel atau jenis hotel yang bebrbeda dengan hotel lainnya sehingga memiliki nilai yang baik dimata wisatawan dan pengunjung yang datang untuk menginap dan menikmati obyek wisata yang ada di lingkungan Sari
Ater Hotel \& Resort, seperti terlihat dalam gambar 10.

Menurut General Manager Sariater Hotel \& Resort, Defrido Reflianto dibandingkan dengan air panas alam serupa di negara lain, kualitas air panas alam Sari Ater adalah Nomor 1 di dunia. Air panas alam Sari Ater jernih, tidak berbau dan suhunya standar untuk berendam:

"Tak heran wisatawan dari 58 negara di dunia sudah berkunjung ke Sari Ater" (dalam web KotaSubang.com, 2018).

Proses komunikasi internal terjadi melalui komunikasi vertikal, komunikasi horsontal dan komunikasi diagonal, melalui proseskomunikasi internal seluruh karyawan dalam organisasi hotel berkewajiban untuk berkomunikasi secara efektifkepada pelanggan mereka (Proctor dan Doukakis, dalam Ruliana, 2016). Untuk berkomunikasi secara efektif pada publik eksternal, mereka harus memiliki dasar yang kuat untuk melakukan komunikasi efektif, sebelum mereka melanjutkan untuk meningkatkan komunikasi eksternal yang efektif sehingga dibutuhkan pelatihan keterampilan komunikasi. Sebuah bisnis hotel dapat membahayakan, jika staf gagal dalam melakukan komunikasi dengan publik eksternal (Proctor dan Doukakis dalam Ruliana, 2014).

\section{Tekanan Strategi dan Tekanan Masyarakat}

Media sosial berada di bawah tekanan dari komunitas pengguna yang kritis dalam sikap terhadap komersialisasi lingkungan media sosial, karena setiap orang dan setiap hubungan adalah unik. Apa yang benar atau berlaku pada sebagian besar orang atau kelompok tertentu belum tentu benar atau berlaku pada diri (Kertamukti, 2013). 


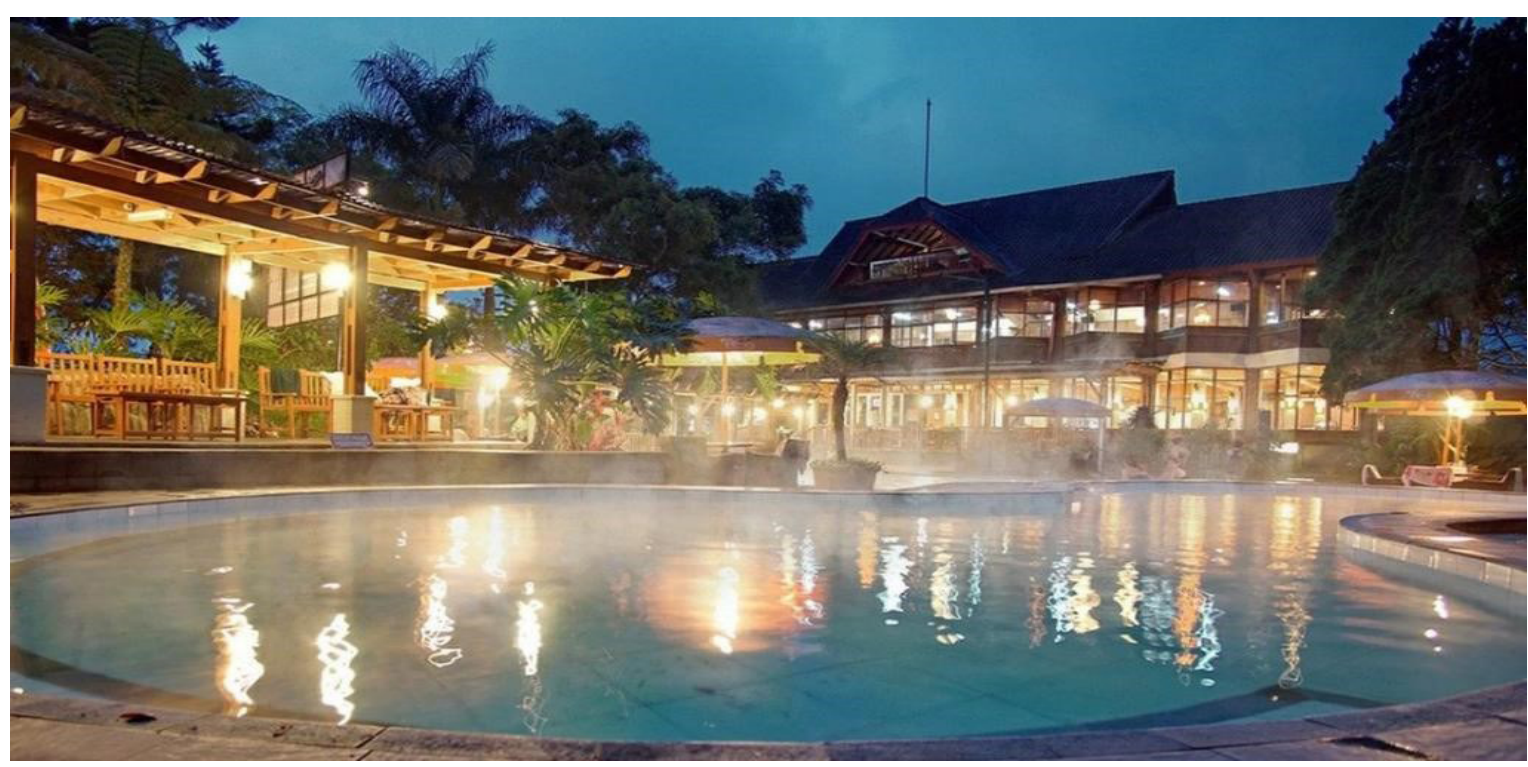

Gambar 10. Obyek Wisata di Lingkungan Sari Ater Hotel \& Resort

Sumber: www.cybevasion.fr/sari-ater-hotei, 2019

Tekanan yang terjadi dalam menggunakan media sosial adalah adanya ulasan yang negative tentang perusahaan namun dilihat dari presentasenya sedikit yang menilai kurang pelayanan yang diberikan petugas Sari Ater Hotel \& Resort. Tekanan lainnya terjadi yang berhubungan dengan isu negatif dan dipublikasikan di media sosial dan media konvensional, adalah ketika terjadi masalah pajak, namun masalah ini segera diatasi oleh pihak komunikasi korporat dan PR sehingga masih dapat menjaga citra perusahaan. Pihak komunikasi korporat dan PR sadar betul perkembangan lingkungan komunikasi di Sari Ater Hotel \& Resort, baik internal maupun eksternal adalah penting.

Berdasarkan pembahasan tersebut di atas, maka dapat diaplikasikan oleh peneliti dalam model komunikasi interaksi pada gambar 11.

Proses komunikasi Sari Ater Hotel \& Resort mengaplikasikan Industri 4.0 dengan sistem yang kompleks dan fleksibel yang melibatkan teknologi digital, teknologi komunikasi jaringan, teknologi komputer, yang dapat di sinkronisasi dalam media sosial yang pihak Sari Ater Hotel \& Resort seperti; Facebook, Google Plus, Twitter, Instagram dan Linkeldn dimana. Di satu sisi, dasar informasi didasarkan pada strategi komunikasi yang dibuat Sari Ater Hotel \& Resort sehingga ada kesatuan dalam produksi pesannya dan, manajemen proses kretif pesan. Sejak lahirnya Internet, interkoneksi antar komputer telah menjadi kenyataan. Internet seluler telah mencapai komunikasi dan kontak sehingga memudahkan orang mengakses informasi. Teknologi internet disadari pihak Sari Ater Hotel \& Resort telah mengubah cara orang berinteraksi, dan Internet seluler dapat dengan cepat menyusup dan memengaruhi pengetahuan masyarakat dalam hal ini pihak konsumen yang ingin mengakses Sari Ater Hotel \& Resort. Strategi Industry 4.0 Sari Ater Hotel \& Resort akan lebih memanfaatkan 


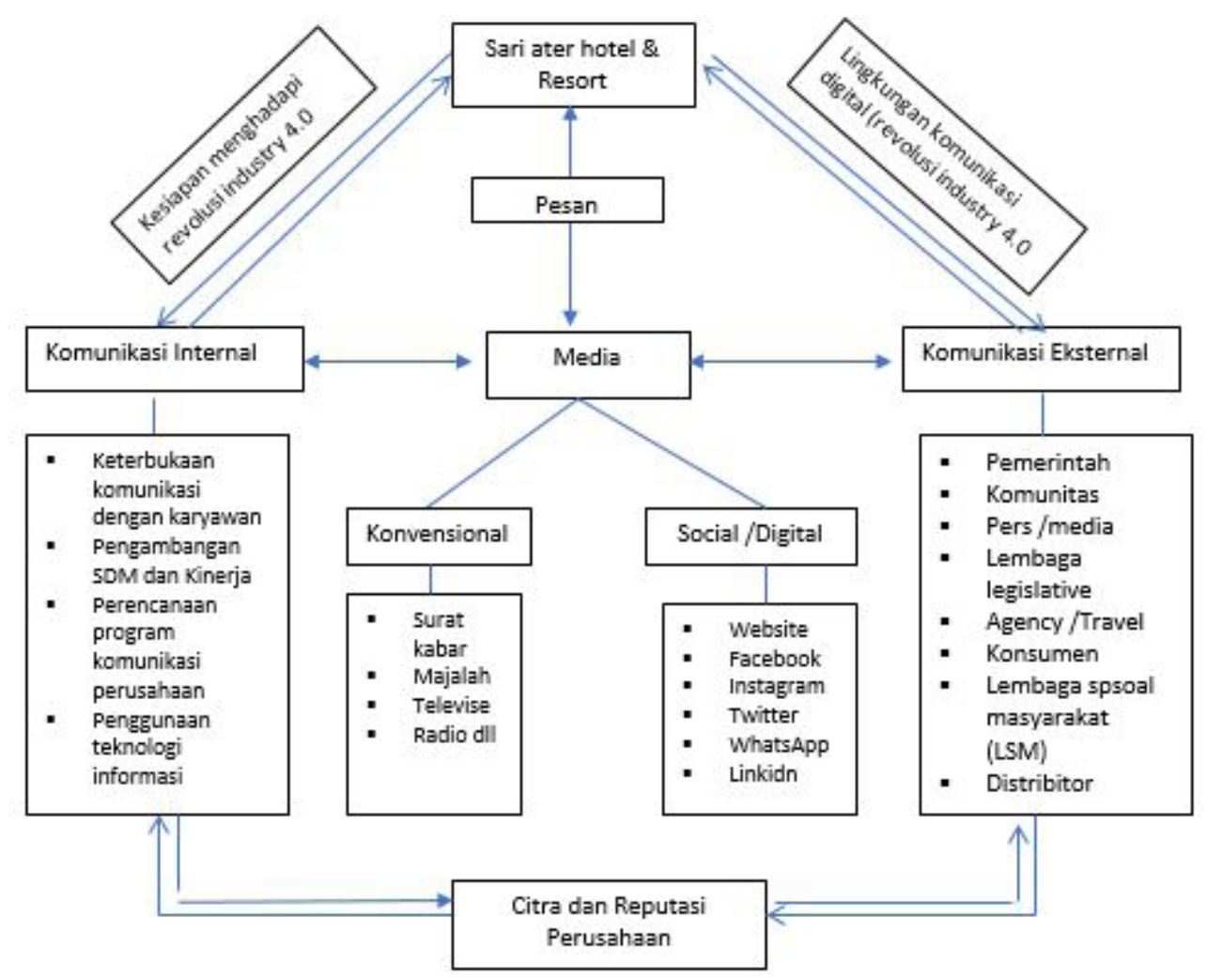

Gambar 11. Model Komunikasi Interaksional

Sunber: Hasil Penelitian, 2019

Internet dan Internet untuk interaksi antara manusia dan mesin yang memungkinkan pembuatan cerdas dan menghasilkan kegiatan komunikasi yang lebih efektif, menyebarkan pesan yang dikehendaki Sari Ater Hotel \& Resort, yang menyadari betul lingkungan komunikasi yang apabila tidak adanya strategi komunikasi yang tepat akan sangat menghambat Sari Ater Hotel \& Resort dengan konsumen. Persiapan ini dilakukan untuk menghadapi tantangan bisnis yang makin global di era media digital, Seperti halnya yang diungkap Vasja Roblek:

"Industry 4.0 is rapidly changing the relations between con-sumers and producers" (Roblek, Meško, \& Krapež, 2016).

Industri 4.0 disadari pihak Sari Ater Hotel \& Resort akan membawa dampak negatif terutama dari sudut pandang sosial dan ekonomi sehingga perlu sekali dibutuhkan strategi pesan yang baik.

\section{Simpulan}

Penelitian ini telah menemukan bahwa model komunikasi korporat Sari Ater yaitu model nilai tambah penggunaan media sosial untuk komunikasi korporat relevan karena ternyata media digital memberi pengaruh terhadap pelaksanaan kegiatan PR Sari Ater Hotel \& Resort bahkan telah dijadikan sebagai media untuk berhubungan dengan publik, baik publik internal maupun publik eksternal. Melalui internet dapat diketahui berbagai informasi maupun isu-isu yang berkembang atau perubahan yang terjadi sehingga seorang praktisi PR Sari Ater Hotel $\&$ Resort dapat mengakses seluruh informasi yang diperlukakan sesuai kebutuhan 
organisasi, namun demikian dalam website Sari Ater Hotel \& Resort tidak ditemukan adanya interaksi antara perusahaan dengan para wisatawan secara langsung, kalaupun ada ulasan atau opini ada di booking.com dan trapadvisor sebagai mitra perusahaan, .

Penelitian ini merekomendasikan implementasi model komunikasi nilai tambah sebagai tanggapan terhadap perkembangan konstan media baru dan perubahan generasi yang terjadi. Implikasi praktis: model nilai tambah untuk komunikasi korporat dapat digunakan sebagai peningkatan model komunikasi konvensional. Model ini memberdayakan perusahaan untuk mempertahankan dan membangun hubungan yang ada dengan para pemangku kepentingan, dan untuk mencari tahu dan menciptakan hubungan baru dengan para pemangku kepentingan yang sebelumnya tidak dapat diakses dan tidak terlihat dan perlu adanya interaksi langsung antara perusahaan dengan para wisatawan untuk menjaga citra dan reputasi perusahaan.

Berdasarkan simpulan dan saran di atas, penelitian ini menemukan model interaksional yang dapat digunakan oleh Sari Ater Hotel \& Resort .

\section{Daftar Pustaka}

Ashuri, Tamar, Dvir Gvisman dan Ruth Halpen. (2018). Watching Me Watching You: How Observational Learning Affects Self-disclosure on Sosial Network Sites?, Journal of ComputerMediated Communication, Volume 23, Issue 1, January 2018, Pages 34-68.

Argenti, Paul. (2016). "How Technology Has Influenced The Field Of Corporate
Communication," Journal of Business and Technical Communication, vol. 20, pp. 357- 370, 2006.

Argenti, Paul. (2010). Corporate Communication. 2nd ed. Boston: McGraw-Hill.

Argenti and C. Barnes. (2009). Digital Strategies for Powerful Corporate Communication, $\mathrm{C}$ o $1 \mathrm{u} \mathrm{m} \mathrm{b} \mathrm{u} \mathrm{s} \mathrm{:}$ McGraw-Hill.

Aavani Desai. (2018). Corporate Communication through Social Media: Strategies for Managing Reputation, Sage Journal, Vol 43, Issue 3.

Diana Ridley. (2012). The Literature Review: A Stepby-Step Guide For Students, 2nd ed. London, Uk: Sage Publications Ltd.

drmarkcamilleri.com. (2016). Corporate Communication, Stakeholder Engagement and Corporate Social Responsibility. Available from: https://drmarkcamilleri. com/2016/06/09/corporatecommunication-stakeholder-engagementand-corporate-social-responsibility/

eMarketerChart.(2016). Social NetworkUsers and Penetration in India, 2014-2020. Available from: https://www.emarketer. com/Chart/Social-Network-UsersPenetration-India-2014-2020/190319. Retrieved Access 22 Mei 2019.

https://media.neliti.com/media/ publications/102703-ID-komunikasidalam-manajemen-reputasi-korp.pdf

https://www.komite.id/2019/04/02/ tourism-4-0-sumber-keunggulaanbaru-menghadapi-persainganpariwisata-global/Selwyn Jerry Boston selwynbostonpr.blogspot.com.

https://www.kotasubang.com/12631/ air-panas-alamnya-no-1-di-duniawisatawan-dari-58-negara-sudahkunjungi-sari-ater. 
Jefkins, Frank. Public Relations, Edisi Ke Lima diterjemahkan oleh Daniel Yadin. Jakarta: Erlangga.

Kazaka Olga. (2011). Corporate Communication in Sosial Media in Latvia, Acta Universitatis Sapientiae, Sosial Analysis, 1,2 .

Kazaka Olga. (2013). Added Value Model: Model of the Corporate Communication in Sosial Media, Journal of Economics, Business and Management, Vol. 1, No. 3, August.

Kertamukti, R. (2013). Dosen dan Mahasiswa dalam (Studi Deskriptif pada Program Studi Ilmu Komunikasi UIN Sunan Kalijaga ). Profetik Jurnal Komunikasi, 06(2), 27-36.

Kuvykaite, Rita dan Zaneta Piligrimiene. (2013). Communication In Sosial Media For Company's Image Formation. Journal Economics And Management:18 (2) ISSN 2029-9338 (Online).

Pace, R. Wayne, Faulers, Don F. (2006). Komunikasi Organisasi. Strategi meningkatkan Kinerja Perusahaan. Remaja Rosdakarya: Bandung.

Pajunen, Kalle. (2011). A "Black Box" of Stakeholder Thinking, Journal of Business Ethics · August.

Prasetyo, H., \& Sutopo, W. (2018). Industri 4.0: telaah klasifikasi aspek dan arah perkembangan riset. Jurnal Teknik Industri, 13(1), 17-26.

Roblek, V., Meško, M., \& Krapež, A. (2016). A Complex View of Industry 4 . 0. 2016. https://doi. org/10.1177/2158244016653987

Ruliana, Poppy dan Ririh Dwiantari, (2015), Strategi Public Relations Hotel dalam Membentuk Citra Objek Wisata,, Jurnal Aspikom, Volume 2 No 4.

Ruliana Poppy, 2014. Komunikasi Organisasi, Teori dan Studi Kasus, Jakarta: Raja Grafindo

Ruliana, Poppy dan Puji Lestari, (2019). Teori Komunikasi dan Aplikasinya terhadap Penelitian. Jakarta: Raja Grafindo Persada

Subagyo. (2018). Revolusi Industri 4.0. Seminar Nasional Re Orientasi Riset dan Inovasi dalam Menghadapi Revolusi Industri 4.0 dan Kurikum 4.0 Di Perguruan Tinggi, Jakarta: SIKOM InterStudi.

Sugiyono. (2017). Metode Penelitian Kuantitatif, Kualitatif, dan R\&D. Bandung: Alfabeta.

Wasesa, Agung Silih dan Jim Macnamara. (2010). Strategi Public Relations, Jakarta: Gramedia.

wadds.co.uk/.../grunig-revisited-digitalcommuni.,https://doi.org/10.1093/jcmc/ zmx003

Wyrwicka, M. K., \& Mrugalska, B. (2017). "Industry 4.0"-Towards Opportunities and Challenges of Implementation. (ICPR), 382-387.

Zhou, K. (2015). Industry 4.0: Towards Future Industrial Opportunities and Challenges. 12th International Conference on Fuzzy Systems and Knowledge Discovery (FSKD), 2147-2152. 